\title{
PENGARUH SIKAP, NORMA SUBJEKTIF DAN KONTROL PERILAKU TERHADAP NIAT BELI PRODUK PADA UMKM CENTER KOTA TARAKAN
}

\author{
THE INFLUENCE OF THE ATTITUDE, SUBJECTIVE NORM AND \\ BEHAVIORAL CONTROL PURCHASING INTENTION OF MICRO, SMALL \\ AND MEDIUM ENTERPRISES PRODUCT IN TARAKAN CITY
}

\author{
Azisah Nurul Khaerani ${ }^{1)}$, Nurjannatul Hasanah ${ }^{2)}$ \\ ${ }^{1) 2)}$ Universitas Borneo Tarakan
}

\begin{abstract}
Abstrak: Penelitian ini bertujuan untuk mengetahui pengaruh sikap, norma subjektif dan kontrol perilaku terhadap niat beli produk pada UMKM Center Kota Tarakan. Penelitian ini menggunakan pendekatan kuantitatif dengan metode survei. Metode pengambilan sampel yang digunakan dalam penelitian ini adalah nonprobability sampling dengan teknik penentuan sampel menggunakan purposive sampling. Sampel dalam penelitian ini adalah masyarakat kota Tarakan yang mengetahui salah satu produk yang dijual pada UMKM Center. Jumlah responden sebanyak 200 orang. Metode analisis menggunakan analisis regresi dengan bantuan program SPSS versi 16.0. Hasil penelitian ini menujukkan bahwa sikap, norma subjektif dan kontrol perilaku berpengaruh positif dan signifikan terhadap niat beli produk pada UMKM Center Kota Tarakan.
\end{abstract}

Kata Kunci : Kontrol Perilaku, Niat Beli, Norma Subjektif, Produk UMKM Center, Sikap

Abstract: The study aims to determine the influence of attitude, subjective norm and behavioral control purchasing intention of micro, small and medium enterprises product in Tarakan City. This research using quantitative appoarch with survey method. Sampling method used in this study was nonprobability sampling with sampling technique by using purposive sampling. The sample in this study is peoples in Tarakan City who know one of product at micro, small and medium enterprises in Tarakan city. Totaling respondent was 200 people. The method of analysis using regression analysis with the help of SPSS program version 16.0. The result of this study indicate that attitude, subjective norm and behavioral control has a positive effect and significant to purchasing intention of micro, small and medium enterprises product in Tarakan city.

Keywords: Attitude, Behavioral Control, Micro, Small and Medium Enterprises Product, Purchase Intention, Subjective Norm 


\section{LATAR BELAKANG}

Pasar bebas merupakan kondisi pasar yang semakin kompetitif serta penuh dengan ketidakpastian, setiap perusahaan akan dihadapkan pada persaingan yang ketat. Hal ini yang mengharuskan perusahaan untuk dapat melakukan aktifitas yang efektif dan efisien. Sehingga perusahan dapat meningkatkan daya saing dan kelangsungan hidup perusahaan dapat terjamin dalam jangka waktu yang lama (Nurul Hidayati, 2011). Tuntutan dari perdagangan bebas dunia terutama masyarakat ekonomi Asean (MEA), yang ditandai dengan semakin meningkat dan ketatnya persaingan. Oleh karena itu, semua industri dituntut kreatifitasnya dalam mencari peluang dan mempertahankan posisinya. Bermunculannya produkproduk baru mendorong usaha-usaha pemasaran produk- produk lokal seperti UMKM, produsen mencari ide - ide kreatif, inovatif, dan keunggulan untuk menang di pasar (Geovanni Da Costa Jong, 2015).

Kantor dan Usaha Mikro, Kecil dan Menengah (KUMKM) Kota Tarakan yang diresmikan pada 20 Februari 2014 oleh Gubernur Kalimantan Utara dan dikelola oleh Dinas Perindustrian, Perdagangan dan Koperasi serta UMKM Kota Tarakan. KUMKM Center merupakan pusat informasi, promosi dan penjualan produk Koperasi, Usaha (Industri) Mikro, Kecil dan Menengah Kota Tarakan. Operasional KUMKM Center ditunjang oleh gedung yang representatif dan terintegrasi dengan ruang pertemuan atau pelatihan dan rumah kemasan. KUMKM Center Kota Tarakan dilengkapi dengan berbagai macam sarana display produk, kulkas, freezer box, showcase, keranjang belanja, strapping machine dan menggunakan aplikasi point of sales dalam pengelolaan data stock barang, transaksi dan pembuatan laporan laporan. Untuk memperluas jangkauan pemasaran produk, KUMKM Center telah membangun aplikasi e-commerce yang berisikan informasi katalog produk dan keranjang belanja untuk bertransaksi secara online. Dengan tersedianya berbagai macam produk pada KUMKM Center Kota Tarakan, masyarakat yang mengunjungi maupun membeli produk tersebut masih minim. Hasil observasi dan wawancara, bahwa pengunjung maupun pembeli pada KUMKM Center hanya berkisar 3 hingga 4 orang setiap harinya. Padahal, harga produk pada KUMKM Center relatif murah dibandingkan dengan produk sejenis yang juga terdapat di beberapa supermarket yang ada di Kota Tarakan. Terdapat 50 pelaku UMKM dan 33 jenis produk yang terdapat di KUMKM Center Kota Tarakan, diantaranya batik, tas batik handmade, sambal dayak, keripik singkong, keripik pisang, keripik tempe, stik kaktus, stik aneka rasa, dodol rumpul laut, brownies rumput laut, nugget rumput laut, jamu, kerajinan tangan, abon dan lain sebagainya (KUMKM Center Kota Tarakan, 2018).

Dalam memilih produk, masyarakat mempunyai berbagai macam pilihan, hal ini disebabkan 
oleh banyaknya industri yang menawarkan produknya dengan berbagai macam jenis yang beredar dimasyarakat. Penentuan produk mana yang akan dibeli oleh konsumen akan melibatkan proses kognitif yang dimulai dari evaluasi terhadap produk tersebut hingga timbulnya niat untuk membeli (Nur Hadiati Endah, 2014). Teori perilaku berencana (Theory of Planned Behavior) merupakan model yang umum digunakan untuk melihat faktor-faktor yang mempengaruhi keputusan dan perilaku pembelian konsumen terhadap produk tertentu. Menurut teori ini sebuah perbuatan diawali dengan niat (intention) dimana niat tersebut dipengaruhi oleh tiga faktor internal yaitu sikap (attitude), norma subjektif (subjective norms), dan persepsi kontrol perilaku (perceived behavioral control).

Sikap merupakan evaluasi konsep secara menyeluruh yang dilakukan oleh pelanggan. Evaluasi dapat diciptakan oleh sistem afektif yang berupa emosi, perasaan, suasana hati dan tanggapan segera dan langsung pada rangsangan tertentu. Sikap ini berupa ketertarikan berbelanja di UMKM Center Kota Tarakan, kesukaan terhadap produk yang ditawarkan, kesenangan dalam berbelanja produk UMKM Center dan keyakinan akan manfaat produk UMKM yang dibelanjakan. Konsep di atas jika diuraikan secara sederhana dan penerapannya terhadap produk pada UMKM Center di Kota Tarakan, bahwa orang memilih atau membeli karena adanya niat. Niat dibentuk oleh adanya sikap, yaitu kombinasi antara keyakinan yang datang dari dalam diri konsumen terhadap produk UMKM Center di Kota Tarakan.

Selain sikap niat beli pada UMKM Center ditentukan oleh subjective norm (norma subjektif) yang merupakan sejauh mana pelanggan memiliki motivasi untuk mengikuti pandangan orang terhadap perilaku yang akan dilakukannya. Jika pelanggan merasa itu adalah hak pribadinya untuk menentukan apa yang akan dia lakukan dan dapat ditentukan oleh orang lain disekitarnya, maka dia akan merasa bahwa pandangan orang tentang perilaku yang akan dilakukannya adalah sesuai, sehingga akan menimbulkan niat untuk membeli suatu produk (Mirna Zulianti, 2012). Jika konsumen mempunyai tanggapan yang positif terhadap produk UMKM Center, maka ia akan positif untuk membeli produk tersebut.

Behaviour control merupakan persepsi individu mengenai mudah atau tidaknya individu untuk melakukan perilaku dan diasumsikan merupakan refleksi dari pengalaman yang telah terjadi sebelumnya juga hambatan - hambatan yang diantisipasi. Mudah atau tidaknya konsumen melakukan belanja sebagai refleksi dari pengalaman masa lampau dan cara mengatasi hambatan-hambatan yang hadir saat ingin berbelanja di UMKM Center. Behavioral control dapat mengukur kemampuan seseorang dalam mendapatkan produk dalam mengambil suatu kegiatan (Mirna Zulianti, 2012). 


\section{RUMUSAN MASALAH}

Adapun rumusan masalah yang di bangun dalam penelitian ini adalah

1. Apakah sikap, norma subjektif dan kontrol perilaku terhadap niat beli produk pada UMKM Center Kota Tarakan secara parsial?

2. Apakah sikap, norma subjektif dan kontrol perilaku terhadap niat beli produk pada UMKM Center Kota Tarakan secara simultan?

\section{TUJUAN PENELITIAN}

Adapun rumusan masalah yang di bangun dalam penelitian ini adalah

1. Mengetahui pengaruh sikap, norma subjektif dan kontrol perilaku terhadap niat beli produk pada UMKM Center Kota Tarakan secara parsial.

2. Mengetahui pengaruh sikap, norma subjektif dan kontrol perilaku terhadap niat beli produk pada UMKM Center Kota Tarakan secara simultan.

\section{LANDASAN TEORI}

\section{$\underline{\text { Teori Perilaku Berencana }}$}

Teori perilaku berencana
(Theory of Planned Behavior)
merupakan model yang umum
digunakan untuk melihat faktor-
faktor yang mempengaruhi
keputusan dan perilaku pembelian
konsumen terhadap produk tertentu.
Menurut Ajzen (1991), faktor sentral
dari perilaku individu adalah bahwa
perilaku itu dipengaruhi oleh niat

individu (behavior) terhadap perilaku tertentu. Niat untuk berperilaku dipengaruhi oleh tiga komponen yaitu (1) sikap (attitude), (2) norma subjektif (subjective norm) dan (3) persepsi kontrol keperilakuan (perceived behavior control). Individu dapat memiliki berbagai keyakinan terhadap suatu perilaku, namun ketika dihadapkan pada suatu kejadian tertentu, sedikit dari keyakinan tersebut yang timbul untuk mempengaruhi perilaku. Sedikit keyakinan inilah yang menonjol dalam mempengaruhi perilaku individu (Ajzen 1991).

\section{$\underline{\text { Sikap }}$}

Sikap adalah konsekuensi positif atau negatif dari melakukan suatu perilaku (behavioral beliefs), berdasarkan hasil evaluasi dari konsekuensi berperilaku (outcome evaluation). Individu memiliki berbagai macam keyakinan terhadap suatu perilaku, apabila dihadapkan suatu kejadian, sedikit dari keyakinan tersebut yang timbul untuk mempengaruhi perilaku (Ajzen 1991). Keyakinan yang menonjol ini adalah behavior belief yaitu keyakinan individu akan hasil suatu perilakul dan evaluasi atas hasil tersebut. Behavior belief akan mempengaruhi sikap terhadap perilaku. Sikap dibentuk oleh keyakinan yang bersumber dari instink (naluri) dan hasil penilaian (evaluasi) yang membentuk persepsi dalam notasi baik atau buruk, senang atau tidak senang, (Ajzen 1991). 


\section{$\underline{\text { Norma Subjektif }}$}

Fishbein dan Ajzen (1991) mendefinisikan norma subjektif sebagai persepsi individu tentang apakah orang penting bagi individu berpikir perilaku harus dilakukan. Apabila individu merasa itu adalah hak pribadinya untuk menentukan apa yang akan dia lakukan, bukan ditentukan oleh orang lain di sekitarnya, maka dia akan mengabaikan pandangan orang tentang perilaku yang akan dilakukannya. Ajzen (1991), Norma subjektif (subjective norms) dibentuk oleh normative belief (keyakinan normatif), yaitu keyakinan terhadap orang lain (kelompok acuan atau referensi) bahwa mereka berpikir subjek seharusnya atau tidak melakukan suatu perilaku atau keyakinan normatif tentang harapan orang lain (kelompok acuan) terhadap dirinya mengenai apa yang seharusnya dilakukan. Motivation to comply (motivasi mematuhi), yaitu motivasi yang sejalan dengan keyakinan normatif atau motivasi yang sejalan dengan orang yang menjadi kelompok acuan.

\section{$\underline{\text { Kontrol Perilaku }}$}

Fisbein dan Ajzen (1991) behavioral control didefinisikan sebagai persepsi seseorang terhadap hambatan dalam melakukan suatu perilaku. Behavioral control memandang pengendalian / kontrol yang dimiliki seseorang terhadap perilakunya berada pada sebuah kontinum dari perilaku yang mudah dilakukan dengan usaha dan sumber daya yang cukup. Behavioral control dibentuk oleh control belief (keyakinan pengendalian), yaitu probabilitas bahwa beberapa faktor menunjang suatu tindakan / perilaku. Power of Control Factor / Access to the Control Factor (kekuatan faktor pengendalian), yaitu akses subjek atau kekuatan subjek terkait faktorfaktor yang menunjang perilaku tersebut.

\section{$\underline{\text { Niat Beli Produk }}$}

Fisbein dan Ajzen (1991) menggambarkan niat beli sebagai suatu situasi seseorang sebelum melakukan suatu tindakan, yang dapat dijadikan dasar untuk memprediksi perilaku atau tindakan tersebut. Berdasarkan Theory of Reasoned Action dari Fishbein dan Ajzen, tindakan seseorang adalah realisasi dari keinginan atau niat seseorang untuk bertindak. Menurut Ajzen (1991), niat adalah kecenderungan seseorang untuk bersedia melakukan atau tidak melakukan sesuatu pekerjaan. Individu memiliki berbagai macam keyakinan terhadap suatu perilaku, apabila dihadapkan suatu kejadian, sedikit dari keyakinan tersebut yang timbul untuk mempengaruhi perilaku. Sedikit keyakinan inilah yang menonjol dalam mempengaruhi perilaku individu (Ajzen 1991).

Hubungan Antara Sikap Terhadap Niat Beli Produk

Munandar

(2014), menemukan sikap berpengaruh positif terhadap niat menggunakan produk perbankan syariah. Penelitian lain juga menunjukkan hasil yang sama, I Wayan Bhakta Pradnyana dan Tjok Gede Raka Sukawati 
(2016) dalam penelitiannya menemukan sikap berpengaruh positif terhadap niat konsumen membeli sepeda motor Honda Vario Techno 125 CBS.

H1 : Sikap berpengaruh positif terhadap niat beli produk pada UMKM Center Kota Tarakan

Hubungan Antara Norma Subjektif Terhadap Niat Beli Produk

Penelitian oleh I Wayan Bhakta Pradnyana dan Tjok Gede Raka Sukawati (2016) menyatakan bahwa norma subjektif berpengaruh positif terhadap niat konsumen membeli sepeda motor Honda Vario Techno 125 CBS. Munandar (2014) dalam penelitiannya menemukan norma subjektif berpengaruh positif terhadap niat menggunakan produk perbankan syariah.

H2 : Norma Subjektif berpengaruh positif terhadap niat beli produk pada UMKM Center Kota Tarakan

Hubungan Antara Kontrol Perilaku Terhadap Niat Beli Produk

Penelitian oleh Jessvita dan Edwin (2014) menyatakan bahwa kontrol perilaku berpengaruh positif terhadap niat beli produk pada SOGO Department Store di Tunjungan Plaza Surabaya. Penelitian tersebut didukung oleh Yohana Agnes Taurusia (2011) dalam penelitiannya yang berjudul Pengaruh Sikap, Norma Subjektif dan Persepsi Kontrol Perilaku terhadap Niat Beli Konsumen Melalui Online Shopping yang menyatakan persepsi kontrol perilaku berpengaruh positif terhadap niat beli konsumen melalui online shopping.

H3 : Kontrol Perilaku berpengaruh positif terhadap niat beli produk pada UMKM Center Kota Tarakan

\section{METODE PENELITIAN}

Jenis penelitian ini adalah penelitian kuantitatif. Sujarweni (2015), penelitian kuantitatif adalah jenis penelitian yang menghasilkan penemuan - penemuan yang dapat dicapai dengan menggunakan prosedur - prosedur statistik atau cara - cara lain dari kuantifikasi (pengukuran). Berdasarkan karakteristik masalah yang diteliti, penelitian ini menggunakan metode survei. Penelitian survei adalah penelitian yang dilakukan untuk mengumpulkan informasi yang dilakukan dengan cara menyusun daftar pertanyaan yang diajukan pada responden. Populasi dalam penelitian ini adalah masyarakat Kota Tarakan yang tidak di ketahui jumlahnya. Menurut Sugiyono (2014), sampel adalah bagian dari jumlah dan karateristik yang dimiliki oleh populasi tersebut. Karena jumlah populasi tidak diketahui sampel penelitian diambil dengan menggunakan teknik nonprobability sampling. Teknik pengambilan sampel yang digunakan purposive sampling, yaitu teknik penetuan sampel dengan pertimbangan atau kriteria - kriteria tertentu (Sugiyono, 2014). Sampel yang digunakan harus dapat mewakili dan mencerminkan populasi yang ada. Sampel dalam penelitian ini adalah masyarakat Kota Tarakan dengan kriteria tertentu yaitu masyarakat yang 
mengetahui produk yang dijual pada UMKM Center Kota Tarakan. Jumlah sampel ditentukan berdasarkan perhitungan dari rumus Hair et. al (2006) dalam penelitian Remalya Foti Fera Manasye Lenggu (2016), menyatakan bahwa untuk mengukur ukuran sampel dihitung antara (5-10) x jumlah indikator. Dari rumus tersebut, pengambilan sampel sebanyak $10 \times 20$ indikator $=$ 200 sampel. Jadi, sampel yang digunakan adalah sebanyak 200 responden.

Teknik pengumpulan data dengan menggunakan kuesioner (angket), merupakan teknik pengumpulan data yang dilakukan dengan cara memberi seperangkat pertanyaan atau pernyataan tertulis kepada responden untuk dijawabnya, (Sugiyono, 2014). Metode pengumpulan data ini yang dilakukan dengan mengajukan lembaran angket yang berisi daftar pertanyaan kepada responden, yaitu pengaruh sikap, norma subjektif, dan kontrol perilaku terhadap niat beli produk pada UMKM Center Kota Tarakan. Skala pengukuran yang digunakan adalah menggunakan skala likert. Skala likert digunakan untuk mengukur sikap, pendapat dan persepsi seseorang atau sekelompok orang tentang fenomena sosial, (Sugiyono, 2014).

Metode analisis data yang digunakan dalam penelitian ini terdiri dari Uji Validitas, Uji Reliabilitas, Uji Normalitas dan Uji Regresi. Pengujian validitas menggunakan Confirmatory Factor Analysis (CFA). Dikatakan valid apabila loading factor $>0,5$. Pengujian reliabilitas, apabila nilai koefisien reliabilitas atau Cronbach's
Alpha > 0.7, maka instrumen penelitian reliabel. Jika nilai Cronbach's Alpha < 0.7, maka instrumen penelitian tidak reliabel (Hair, et al, 1998 dalam Penelitian Burhanudin, 2010). Uji normalitas menurut Ghozali (2011) bertujuan untuk menguji apakah dalam model regresi, variabel pengganggu atau residual memiliki distribusi normal. Prosedur uji normalitas dilakukan dengan uji kolmogorov smirnov. Jika nilai signifikansi uji kolmogorov smirnov > 0.05 (5\%), maka dapat disimpulkan bahwa residual model regresi berdistribusi normal. Analisis regresi dilakukan berdasarkan perbandingan nilai thitung masingmasing koefisien regresi dengan nilai ttabel sesuai dengan tingkat signifikansi yang digunakan.

\section{HASIL PENELITIAN}

\section{$\underline{\text { Uji Validitas }}$}

Pengujian validitas dilakukan melalui Conformatory Factor Analysis (CFA) yang mempunyai loading factor yang valid yaitu > 0,50 . Berdasarkan hasil pengujian validitas, Indikator SK 6, NS 4, KP 2, KP 6, dan NB 4 dikeluarkan karena tidak memenuhi persyaratan loading factor yaitu hasil dari rotated component matrix pada pengujian CFA $<0,50$ sehingga dikatakan tidak valid.

\section{$\underline{\text { Uji Reliabilitas }}$}

Pengukuran reliabilitas dapat dilakukan dengan uji statistik Cronbach Alpha $(\alpha)$. Suatu konstruk atau variabel dinyatakan reliabel jika memberikan nilai Cronbach Alpha > 
0.7, maka instrumen penelitian reliable (Hair, et al, 1998 dalam Penelitian Burhanudin, 2010). Hasil pengujian reliabilitas disajikan pada tabel 4.9 yang menunjukkan nilai rule of thumb Cronbach's Alpha berkisar antara 0,880 sampai 0,892 . Dengan demikian semua item pertanyaan memenuhi persyaratan reliabilitas.

\section{$\underline{\text { Uji Normalitas }}$}

Penggujian $\begin{array}{r}\text { normalitas } \\ \text { kolmogorov }\end{array}$
dilakukan dengan
smirnov. Jika nilai signifikansi uji
kolmogorov smirnov > 0.05 (5\%),
maka dapat disimpulkan bahwa
residual model regresi berdistribusi
normal. Hasil uji normalitas
Kolmogorov-Smirnov, menunjukkan
bahwa nilai Asymp. Sig. (2-tailed)
sebesar 0,399. Hasil tersebut lebih
besar dari nilai signifikans uji
kolmogorov smirnov 0,05 sehingga
dapat disimpulkan bahwa data
berdistribusi normal.

\section{$\underline{\text { Uji Hipotesis }}$}

Hipotesis 1 : Sikap berpengaruh positif terhadap niat beli produk pada UMKM Center Kota Tarakan

Ringkasan hasil uji hipotesis menunjukkan bahwa hubungan tersebut memiliki nilai $\beta 0.247$ dan nilai thitung sebesar 3.570 signifikan pada $\mathrm{a}=0.05$ (one tailed) dengan nilai ttabel 1.971, berarti nilai thitung $>$ ttabel. Hal tersebut menunjukkan bahwa sikap berpengaruh positif dan signifikan terhadap niat beli produk pada UMKM Center Kota Tarakan. Dengan demikian dapat disimpulkan bahwa hipotesis 1 diterima.
Hipotesis 2 : Norma Subjektif berpengaruh positif terhadap niat beli produk pada UMKM Center Kota Tarakan

Ringkasan hasil uji hipotesis menunjukkan bahwa hubungan tersebut memiliki nilai $\beta 0.149$ dan thitung sebesar 2.259 signifikan pada $\mathrm{a}=0.05$ (one tailed) dengan nilai ttabel 1.971, berarti nilai thitung > ttabel. Hal tersebut menunjukkan bahwa norma subjektif berpengaruh positif dan signifikan terhadap niat beli produk pada UMKM Center Kota Tarakan. Dengan demikian dapat disimpulkan bahwa hipotesis 2 diterima.

Hipotesis 3 : Kontrol Perilaku berpengaruh positif terhadap niat beli produk pada UMKM Center Kota Tarakan

Ringkasan hasil uji hipotesis menunjukkan bahwa hubungan tersebut memiliki nilai $\beta 0.263$ dan thitung sebesar 3.751 signifikan pada $\mathrm{a}=0.05$ (one tailed) nilai ttabel 1.971 berarti nilai thitung > ttabel. Hal tersebut menunjukkan bahwa kontrol perilaku berpengaruh positif dan signifikan terhadap niat beli produk pada UMKM Center Kota Tarakan. Dengan demikian dapat disimpulkan bahwa hipotesis 3 diterima.

\section{PEMBAHASAN}

Pembahasan

Sikap

Berpengaruh Positif dan Signifikan Terhadap Niat Beli Produk pada UMKM Center

Pada hasil uji hipotesis menunjukkan bahwa sikap berpengaruh positif dan signifikan terhadap niat beli produk pada UMKM Center Kota Tarakan. 
Artinya, bahwa semakin tinggi sikap pada produk UMKM Center, maka semakin tinggi niat beli konsumen terhadap produk UMKM Center. Sehingga, apabila konsumen yakin akan kualitas produk, konsumen menggunakan produk adalah hal yang penting, konsumen bangga menggunakan produk, konsumen nyaman menggunakan produk dan produk tersebut bermanfaat dan berguna maka akan mengarah pada perilaku yang akan diwujudkan dalam bentuk niat beli atau semakin memunculkan niat beli pada produk UMKM Center Kota Tarakan.

Pembahasan Norma Subjektif Berpengaruh Positif dan Signifikan Terhadap Niat Beli Produk pada UMKM Center

Pada hasil uji hipotesis menunjukkan bahwa norma subjektif berpengaruh positif dan signifikan terhadap niat beli produk pada UMKM Center Kota Tarakan. Artinya, bahwa semakin tinggi norma subjektif seseorang pada produk UMKM Center, maka semakin kuat niat beli pada produk UMKM Center. Sehingga, konsumen akan berniat melakukan pembelian jika ia mempersepsikan bahwa orang-orang lain yang penting disekitarnya berfikir bahwa ia seharusnya melakukan hal itu. Dalam penelitian ini, konsumen memiliki norma subjektif terhadap produk UMKM Center dengan mempertimbangkan pendapat keluarga mengenai kualitas produk pada UMKM Center. Selain itu juga, pengalaman teman atau sahabat serta pendapat tetangga mengenai kenyamanan berbelanja juga menjadi pertimbangan konsumen dalam memunculkan niat beli produk pada UMKM Center.

Pembahasan Kontrol Perilaku Berpengaruh Positif dan Signifikan Terhadap Niat Beli Produk pada UMKM Center

Pada hasil uji hipotesis menunjukkan bahwa kontrol perilaku berpengaruh positif dan signifikan terhadap niat beli produk pada UMKM Center Kota Tarakan. Artinya semakin individu merasakan banyak faktor pendukung dalam mendapatkan produk UMKM Center maka semakin tinggi niat untuk membeli produk UMKM Center. Dalam penelitian ini, konsumen memiliki kontrol perilaku terhadap produk UMKM Center apabila didukung oleh sumber daya atau kemampuan masyarakat untuk membeli produk UMKM Center. Selain itu juga, apabila konsumen yakin dapat membeli, ada banyak pilihan mengenai produk, informasi mengenai produk jelas dan lengkap, dan membeli produk tersebut hal yang mudah maka akan semakin memunculkan niat beli terhadap produk UMKM Center

\section{KESIMPULAN}

Berdasarkan tujuan dan rumusan masalah pada penelitian ini, dari hasil penelitian dan pembahasan yang dilakukan maka dapat ditarik kesimpulan, sikap, norma subjektif berpengaruh positif dan signifikan terhadap niat beli produk pada UMKM Center, dan kontrol perilaku berpengaruh positif dan signifikan terhadap niat beli produk pada UMKM Center. Artinya, bahwa apabila konsumen yakin akan kualitas produk, konsumen 
menggunakan produk adalah hal yang penting, konsumen bangga menggunakan produk, konsumen nyaman menggunakan produk dan produk tersebut bermanfaat dan berguna dengan mempertimbangkan pendapat keluarga mengenai kualitas produk pada UMKM Center, pengalaman teman atau sahabat serta pendapat tetangga mengenai kenyamanan berbelanja juga menjadi pertimbangan konsumen dan didukung oleh sumber daya atau kemampuan masyarakat untuk membeli produk UMKM Center, konsumen yakin

dapat membeli, ada banyak pilihan mengenai produk, informasi mengenai produk jelas dan lengkap, dan membeli produk tersebut hal yang mudah maka akan semakin memunculkan niat beli terhadap produk UMKM

\section{SARAN}

Berdasarkan hasil penelitian yang telah dilakukan penulis membuat saran bagi beberapa pihak yang berkepentingan antara lain adalah sebagai berikut:

1. Bagi Pemasar

Bagi pemasar penting untuk memperhatikan faktor - faktor yang mempengaruhi sikap, norma subjektif dan kontrol perilaku konsumen dalam membeli produk produk UMKM sehingga produk lokal dapat menjadi prioritas konsumen dalam membeli produk untuk memenuhi kebutuhan sekunder. Hal itu dapat terjadi jika pemasar mempertahankan kualitas produk dan mengembangkan kearah yang lebih baik agar dapat meningkatkan volume penjualan produk UMKM Center untuk memenuhi kebutuhan pasar serta meningkatkan promosi agar produk UMKM lebih banyak dikenal masyarakat luas.

2. Bagi Konsumen

Konsumen sebaiknya

memperhatikan kualitas produk lokal, yang nantinya akan berdampak baik bagi pelaku UMKM maupun bagi pemerintah. Hal ini penting untuk dilakukan dengan tujuan untuk melestarikan dan mneingkatkan produk - produk lokal Kota Tarakan agar lebih dikenal masyarakat luas.

3. Bagi Peneliti

Dalam penelitian ini menggunakan metode nonprobability sampling dengan teknik pengambilan sampel dengan menetapkan kriteria tertentu atau teknik purposive sampling, sehingga sangat disarankan untuk peneliti selanjutnya menggunakan metode lainnya dan teknik pengambilan sampel yang berbeda agar dapat menghasilkan variasi dalam penelitian. Bagi penelitian selanjutnya agar mengembangkan dengan menambahkan variabel untuk memperkuat pengaruh atau hubungan antara variabel dependen dan independen yang ada pada penelitian ini sebab kemampuan variabel sikap, norma subjektif dan kontrol perilaku terhadap niat beli produk UMKM Center masih kecil yaitu sebesar 0,240 atau sebesar $24 \%$.

\section{DAFTAR PUSTAKA}

Ajzen, I., 1991. The Theory of Planned Behavior. Organizational Behavior and 
Human Decision Processes. 50: 179-211.

Anggelina, Jessvita dan Edwin Japarianto. 2014. Analisis Sikap, Subjective Norm dan Perceived Behavioral Control Terhadap Purchase Intention Pelanggan SOGO Department Store di Tunjungan Plaza Surabaya. Jurnal Strategi Pemasaran. Vol. 2 No.1

Burhanudin. 2010. Theory of Planned Behavior : Aplikasi Pada Niat Konsumen Untuk Berlangganan Surat Kabar Harian Kedaulatan Rakyat Di Desa Donotirti, Kecamatan Kretek, Kabupaten Bantul. Jurnal

Dharmmesta, Basu Swastha. 1998. Theory of Planned Behavior Dalam Penelitian Sikap, Niat dan Perilaku Konsumen. KELOLA No. 18/VII/1998. ISSN : 0853-7046.

Endah, Nur Hadiati. 2014. Perilaku Pembelian Kosmetik Berlabel Halal Oleh Konsumen Indonesia. Jurnal Ekonomi dan Pembangunan. Vol 22 No 1

Ernawati. 2011. Pengaruh Sikap, Norma Subjektif, Kontrol Perilaku Yang Dipersepsikan, Dan Sunset Policy Terhadap Kepatuhan Wajib Pajak Dengan Niat Sebagai Variabel Intervening. Jurnal. Universitas Brawijaya. Malang.

Ghozali, Imam. 2012. Aplikasi Analisis Multivariat dengan Program IBM SPSS 20 Update PLS Regresi.
Semarang: Badan Penerbit Universitas Diponegoro.

Hair, J.F., W.C. Black, B.J. Babin, R.E. anderson, RL. Tatham. 2006. Multivariate Data Analysis , 6 Ed., New Jersey : Prentice Hall

Herlina, Sri. 2012. Pengaruh Sikap, Norma Subyektif dan Kontrol Keperilakuan terhadap Niat Membeli Handphone Merek Nokia. Universitas Kristen Immanuel Yogyakarta. Jurnal Hidayati, Nurul. 2011. Strategi Bisnis Usaha Mikro Kecil Menengah (UMKM) Dalam Mengembangkan Usahanya (Studi pada Industri Ikat Tenun di Parengan Kecamatan MaduranLamongan). Universitas Pembangunan Nasional "Veteran" Jawa Timur.

Imelda, Sri, Rofi'i, Huwaida Hikmayanti. 2014. Pengaruh Sikap dan Norma Subjektif Terhadap Minat Konsumen (Studi pada Pengguna Refill Tinta Printer Dataprint di Banjarmasin). Jurnal SMART Study dan Management Research. STIE STEMBI Bandung

Jong, Geovanni Da Costa. 2015. Pengaruh Kualitas Produk, Promosi dan Harga Terhadap Keputusan pembelian pada Produk Unggulan UMKM di Galeri Cinderamata Surabaya. Universitas Narotama Surabaya. Jurnal

Lenggu, Remalya Foti Fera Manasye. 2016. Pengaruh Sikap dan Norma Subyektif pada Niat Beli di Centro 
Department

Yogyakarta. Jurnal

Munandar. 2014. Pengaruh Sikap

dan Norma Subyektif

Terhadap Niat Menggunakan

Produk Perbankan Syariah

Pada Bank Aceh Syariah Di

Kota Lhokseumawe. Jurnal

Visoner \& Strategi. Vol 3 No

2 p. $73-80$

Pradnyana, I Wayan Bhakta dan Tjok Gede Raka Sukawati. 2016. Pengaruh Sikap dan Norma Subyektif Terhadap Niat Konsumen Membeli Sepeda Motor Honda Vario Techno 125 CBS. E-Jurnal Manajemen Unud. Vol 5 No

Ramdhani, Neila. 2011. Penyusunan

Alat Pengukur Berbasis Theory of Planned Behavior. Buletin Psikologi. Vol 19 No 2 p. $55-69$

Sekaran, Uma. 2006. Metode Penelitian Bisnis. Jakarta : Salemba Empat

Sigit, Murwanto. 2011. Pengaruh Sikap dan Norma Subyektif Terhadap Niat Beli Mahasiswa Sebagai

Konsumen Potensial Produk Pasta Gigi Close Up. Jurnal Siasat Bisnis. Vol. 11 No. 1.

Sihombing. 2004. Hubungan Sikap

Dan Perilaku Memilih Satu

Merek : Komparasi Antara

Theory Of Planned Behavior

Dan Theory Of Trying.

Disertasi. Universitas Gadja Mada. Yogyakarta.

Sugiyono. 2014. Metode Penelitian Bisnis. Bandung: Alfabeta

Sujarweni, Wiratna. 2015. Metodologi Penelitian Bisnis dan Ekonomi. Yogyakarta: Pustakabarupress
Taurusia, Yohana Agnes. 2011. Pengaruh Sikap, Norma Subyektif dan Persepsi Kontrol Perilaku Terhadap Niat Beli Konsumen Melalui Online Shopping. Universitas Atma Jaya Yogyakarta. Jurnal

Wibowo, Dimas Hendika. Zainul Arifin, dan Sunarti. 2015. Analisis Strategi Pemasaran Untuk Meningkatkan Daya Saing UMKM (Studi pada Batik Diajeng Solo). Jurnal Administrasi Bisnis.Vol.29 No. 1

Yohana. 2011. Pengaruh Sikap, Norma Subyektif, Dan Persepsi Kontrol Perilaku Terhadap Minat Beli Konsumen Melalui Online Shopping. Tesis. Universitas Atmajaya Yogyakarta.

Zulianti, Mirna. 2012. Analisis Pengaruh Sikap, Norma Subjektif dan Persepsi Kontrol Perilaku Terhadap Niat Beli Pelanggan (Survey pada Pelanggan Sogo Department Store di Paris Van Java Mall Bandung). Jurnal

http://septyani-wacanafpsi13.web.unair.ac.id/artikel detail-12599PerilakuTheory-of-Planned-Behavior. html. Diakses Tgl 27 November 2017.

http://en.wikipedia.org/wiki/Theory_ of_planned_behavior.

Diakses Tgl 27 November 2017

http://disperindagkop.tarakankota.go. id. Diakses pada Tanggal 28 November 2017 pukul 22:15 